\title{
Panel to propose shake-up for NASA labs
}

Washington. A panel set up to review the 12 research centres run by the US National Aeronautics and Space Administration (NASA) has concluded that some of the work should be consolidated to avoid duplication, and that other work should be farmed out to industry and universities.

But a draft report describing the panel's recommendations stops short of calling for any of NASA's research centres to be closed, and dodges the question of which functions should be cut at which locations.

These shortcomings drew criticism last week from NASA's external advisory council, which was briefed on the draft report by the panel's chairman, John Foster, a former head of research at the Department of Defense. As a result, the panel may recommend specific cuts when it issues its final report in early March.

The Foster panel, part of a review of federal laboratories which is scheduled to be completed in April, is NASA's equivalent to the Galvin commission that recently reported on the Department of Energy's laboratories (see Nature 373, 463; 1995). A similar exercise is being carried out at the Department of Defense.

NASA's centres range from research-orientated laboratories such as the Ames Research Center near San Francisco and the Goddard Space Flight Center in Maryland, to the Johnson and Kennedy Space Centers, which are more focused on human spaceflight. Since NASA was founded in 1958, each centre has developed capabilities in a wide range of disciplines - and Foster says that is part of the problem.

"Almost every centre is into almost everything," he told the advisory council at a meeting in Washington last week. While some overlap is good, Foster said, much of it is unnecessary. In an era of high-speed communications, for example, he questioned the need for each laboratory to have its own state-of-the-art computer facilities and fleet of aircraft.

Rather than competing as independent fiefdoms, said Foster, the centres "have to become dependent on one another". Achieving that, he said, "means shutting down some of the capabilities in many of the centers".

The panel also recommends that the space agency should transfer to industrial and university contractors some research now carried out in-house at the centres. Some centres might even be turned over entirely to universities says Foster, in much the same way that the California Institute of Technology in Pasadena operates the Jet Propulsion Laboratory.

But the "quick and dirty" study, which only began last October, contains few specific proposals. Panel members who briefed the advisory council last week admitted they had had neither the time nor the expertise to examine in detail which programmes could be cut or transferred out of the centres.

Ironically, NASA's own cost-cutting exercises over the coming months are likely to be much harsher. Even before Congress starts whittling away at its budget, the space agency is already facing serious financial problems later in the decade.

The White House's Office of Management and Budget (OMB) informed NASA managers in mid-January that the agency's budget will drop from $\$ 14.3$ billion in 1996 to $\$ 13.1$ billion in 2000 . Much of this reduction is to pay for President Bill Clinton's proposed middle-class tax cut.

The administration has further specified that the reductions should not come out of

\section{Italy retains existing concorso rules}

Munich. In his first public statement as Italy's new minister for research and universities, Giorgio Salvini last week announced his decision to call a new concorso - the public competition for full-time university academic positions - claiming that universities can no longer afford to wait for agreement on new rules.

Salvini also announced his support for a three-year plan for research and development in Italy, which is now before parliament. The plan would hold the budgets for most research agencies at current levels. But it cuts funding for the National Agency for New Technology, Energy and the Environment (see Nature 372, 393; 1994).

There has been widespread demand in Italy for many years for reform of the system of academic promotion because it lacks transparency and formal criteria for deci- sion-making and it is therefore seen as being vulnerable to abuse.

Umberto Colombo, research minister until last summer, initiated a reform of the system, and his successor Stefano Podestá drafted a bill with this objective. But although some of the proposals were widely accepted, such as the requirement that all candidates for tenure should have a $\mathrm{PhD}$, other proposals proved more controversial.

For example, there was considerable opposition to a proposal in the bill that long-serving associate professors could become full professors simply with the agreement of a local university committee.

Salvini has now decided to start immediately a new series of concorsi for full and associate professorships according to the existing rules. The last full concorso took place in 1989.

Alison Abbott the space station's $\$ 2.1$ billion annual budget. Daniel Goldin, the administrator of NASA, has imposed additional constraints by safeguarding new projects, particularly research into a new Reusable Launch Vehicle (see Nature 373, 180; 1995). "If we have budget problems, we are not going to cut this programme," Goldin told the advisory council.

That challenge has sent NASA's money managers into something of a panic. "We have no idea how we're going to take [the cut]," Malcolm Peterson, the agency's deputy comptroller, told the advisory council. Goldin's solution, which he says is going to be "very painful", is to cut back on people and infrastructure, not programmes.

The agency plans to halve its Washington headquarters staff, and may slash its total work force, currently more than 22,000 , by as much as a third. Shutting down whole centres would be the most drastic option. But it would also create political problems with congressmen affected by the loss of jobs in their states.

Tony Reichhardt

\section{Merck releases first 'gene index' sequences}

London. Merck \& Co., the US-based pharmaceutical company, announced last week that, under a project launched five months ago with researchers from Washington University in St Louis, Missouri, it is making publicly available the first 15,000 expressed human gene sequences that have resulted from a collaborative effort to identify cDNA clones for expressed human genes.

The goal of the project, known as the Merck Gene Index, is to process about 300,000 human gene sequences over the next 18 months, with sequence data being submitted to the Expressed Sequence Tag (EST) division of Genbank for immediate distribution at an anticipated rate of 4,000 sequences a week.

The decision to make the gene sequences freely available to researchers was said at the time to be a response to a decision by Human Genome Sciences, following a \$125million agreement with Merck's rival SmithKline Beecham, to impose conditions on the terms under which scientists would be allowed access to sequences obtained by its Institute of Genomic Research (TIGR) (see Nature 365, 371; 1994).

Meanwhile TIGR has announced that, working in collaboration with various chromosome-mapping laboratories in both the United States and France, it intends to construct an expression map of the human genome, pinpointing the location of individual genes. TIGR says that the mapping will start with 40,000 ESTs that are already publicly available. 